\title{
Migration of Television Audience to Digital Media: Impacts on TV Schedule and Journalism
}

\author{
By Valdecir Becker* \\ Daniel Gambaro ${ }^{\dagger}$ \\ Aline Crisnir \\ Samara Coutinho
}

\begin{abstract}
This article discusses the audience migration between Brazilian television and digital media. Since 2000, Brazilian free-to-air TV audience dropped by 28\%. In the same period, Internet access increased $400 \%$, and digital paid TV, more than 500\%. The phenomenon accentuated after 2006, when pay TV had begun to grow on average $30 \%$ per year, and the Internet, 26\%. A statistical comparison between this fall of audience with the increase of pay TV subscribers and growth of broadband Internet access shows that there is a migration of free-to-air TV audience towards these two media. Nowadays, one third of Brazilian population has access to pay TV and more than half use the Internet. Through empirical investigation and statistical analysis, this paper investigates the implications for such decrease and the motivation of audience migration. The most important consequences are: a partial reformulation of television schedule, programme focus and targets; transmedia productions, including new web narratives; focus on mobile applications, with interactivity and public participation; and new approaches on newscasts, which are becoming more informal, focused on opinion and local news.
\end{abstract}

Keywords: audience migration, audience research, new media, television

\section{Introduction}

Brazil represents, today, a sizable part of total advertisement expenditures worldwide, being the $6^{\text {th }}$ market according to the recent data released by Zenith Optmedia ${ }^{1}$. Television is the major communication medium in Brazil in terms of revenue, with $2 / 3$ of total advertisement investment directed to TV. The same occurs in the reach of television: Researches show that $65 \%$ of Brazilian population watch free-to-air TV on a daily basis, spending around 3.5 hours every day in front of the TV set (Brasil, 2014, p. 19). Free-to-air TV is also the biggest medium in terms of penetration, present in $97 \%$ of Brazilian homes (IBGE, 2012). There is a predominance of aired TV. Pay TV reaches a little more than $1 / 3$ of Brazil's population, in spite of its more than $200 \%$ growth in the last five years (Brasil, 2014; ANATEL, 2014). Television also performs an

\footnotetext{
"Professor, Federal University of Paraiba, Brazil. 'Professor, Anhembi Morumbi University, Brazil. ${ }^{\star}$ Researcher, Federal University of Paraiba, Brazil. Researcher, Federal University of Paraiba, Brazil. ${ }^{1}$ See: http://www.zenithoptimedia.com/.
} 
even more important role in comparison to internet, since $53 \%$ of the population does not access the web (Brasil, 2014, p. 48).

The difficulty in accessing other media has been keeping television as the largest and the main source of information and cultural production. Traditionally, the Brazilian population gets informed through television (Hoineff, 2001).

As regards the total advertisement investment in Brazilian market, $66.5 \%$ were invested in free-to-air TV in 2013, according to data released by Mídia Dados Brasil (Grupo de Mídia São Paulo, 2014). In comparison, radio obtained $4.1 \%$, pay TV $4.9 \%$, and Internet $4.5 \%$.

Nonetheless, even with such prevalence, the aired TV has been facing constant fall in audience ratings. The number of turned-on TV sets decreases year after year and the TV networks have lost 28\% audience from year 2000 to 2013. This represents at least minus two points per year in the total audience of the five major commercial TV networks. The principal and most traditional shows, such as telenovelas, newscasts, and reality shows have suffered decline in their audience. In absolute numbers, the aired TV lost the audience of 1.15 million people in the last 14 years only in the Sao Paulo Metropolitan Region.

It is important to report the most important Brazilian television market is the city of Sao Paulo, which, by the time of the gathering of information for this present study, had a 760-household sample sending information minute to minute, which is considered real time audience measurement (Jauset, 2000). TV broadcasters use this database as a guidance to construct the immediate programming plan. Actually, due to the great economical weight and the concentration of broadcasters and advertising agencies in the city ${ }^{1}$, all information regarding the Brazilian TV audience is based on the measurements held in Sao Paulo Metropolitan Region. For the same reason, this study focuses on the analysis of data of this same region.

This paper investigates and quantifies this fall in audience ratings, showing that there is a migration of the public to digital media, such as Internet and pay TV. By analysing the impact of this migration, this work shows that television begins to react to the fall in audience, with changes in the programming profile, especially in journalism.

\section{Methodology}

Audience is defined as "the collective term for the 'receivers' in the simple sequential model of the mass communication process" (McQuail, 1997, p. 1). In other words, the audience comprises the readers of printed press, radio listeners, television viewers, and users of digital communication technologies, such as the Internet (Bermejo, 2007).

\footnotetext{
${ }^{1}$ The largest TV networks are headquartered in the city of São Paulo, where their national network central stations are also located. The only exception is Rede Globo, whose national network central station is located in Rio de Janeiro, but also has a station and studios in São Paulo. Furthermore, the eight biggest advertisement agencies have head-offices in São Paulo, thus concentrating almost the entire publicity and television markets in this town.
} 
The audience measurement results in a projection of the total number of viewers exposed to a TV programming from a statistically defined sample. The measurement of audience ratings reflects the total number of people or households in the sample that actually tuned in a determined channel. The quantity of people predominates in Brazil. According to the Ibope website, each percentage point corresponded to 62 thousand households and 185 thousand people in Sao Paulo Metropolitan Region in 2013. The audience rating is expressed in points. Each audience point represents one percentage point of the sample, consequently, one percent of population.

For this study, the Brazilian TV audience ratings between years 2000 to 2013 have been analysed to obtain the above-mentioned characteristics of TV viewership. The average monthly ratings have been calculated on the basis of the average daily rating of each broadcaster (from 7:00 am to 12:00 pm) and then the average annual rating. Only the viewership of TV channels with more than one point in audience has been considered statistically relevant (Magalhães \& Lima, 2011), namely Globo, TV Record, SBT, Band e Rede TV. In this presentation, any mention of Brazilian TV audience refers to these five networks.

Since the 1970s decade, the leader in audience has been Rede Globo, receiving more than $50 \%$ of the total advertising investment in television in the country (Grupo de Mídia Sao Paulo, 2014). Globo profited 6.3 billion dollars in 2013 and is today the largest media company in Latin America (Globo Domination, 2014). These numbers also make Globo one of the largest TV networks in the world, figuring amongst the Top Thirty Global Media Owners, released by Zenith Optimedia. Rede Globo reaches $13.6 \%$ of average daily audience.

TV Record, associated to The Universal Church (IURD) and Sistema Brasileiro de TeleviSao (SBT), of entrepreneur and TV Host Silvio Santos, fight for the second place in audience. TV Bandeirantes (Band) appears in $4^{\text {th }}$ place, with an average daily audience of $2.36 \%$ in 2013 , followed by RedeTV, with $1 \%$.

As a side note, we should consider that Public and State TV networks have statistically insignificant audiences, which generates the total predominance of commercial TV. Considering the audience ratings, the sum of all public and State TV networks does not reach $1 \%$. Consequently, these channels have minor impact on the dynamics of audience and on the programming strategies of commercial broadcasters.

The proposed analysis neglects all other channels as their audience together amounted to less than $1 \%$ in the ratings during the analysed period (from 2000 to 2013). To avoid any distortion in data, those channels have been grouped together with pay TV ratings and identified under the terminology OCN. In a similar way, the term OPA represents other devices connected to TV set, such as external media players, video game consoles, personal computers, etc. Finally, the last analysed item is the total number of turned-on television sets (TTL). This number allows generating analyses on the evolution of television as a medium and its importance on people's daily life. This 
proposed methodology follows that of Ibope, a company that measures the audience in Brazil and publishes its ratings.

\section{Data Analysis}

From the analysis of the audience data published by Ibope from 2000 to 2013, some noticeable patterns point to loss of viewership in front of the TV set, both in percentage and in absolute values.

Figure 1 shows the variation in the sum of the main broadcasters' audience. While in 2006 the five main commercial broadcasters had together $38.75 \%$ of the audience, in 2013 they had only $28.26 \%$, representing $10.49 \%$ loss in audience. In relative terms, $27 \%$ of the audience (more than one quarter) stopped watching one of the five main aired channels. Considering the entire period of analysis, from 2000 to 2013, the fall has been greater than $28 \%$.

Figure 1. The Variation in the Sum of the Main Brazilian Broadcasters' Audience

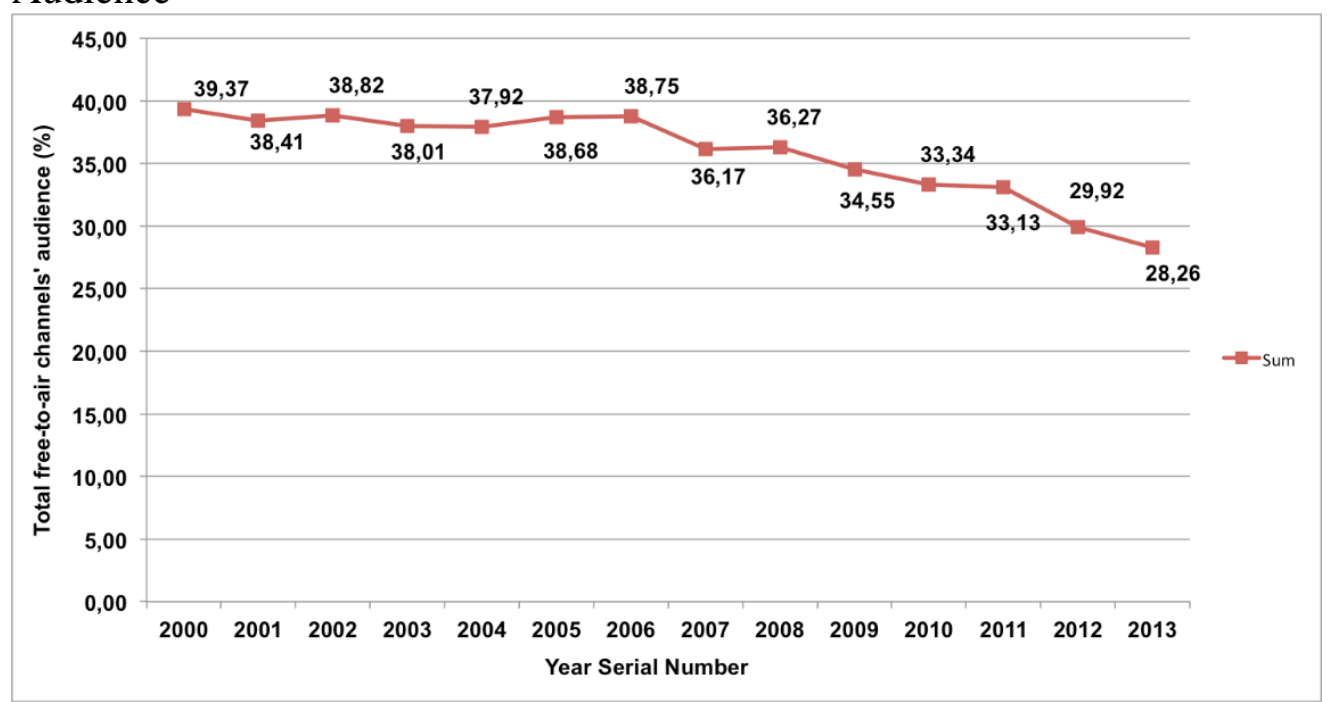

Source: Compilation of data acquired from Ibope.

The examination of the total of turned-on TV sets (TTL) in the same period shows little decrease in numbers in spite of the oscillation during the 14 years, as can be observed in Figure 2. In the first year of analysis, an average of $45.45 \%$ of TV sets had been turned on during the timeslot from 7:00 am to midnight. This number has fallen to $41.70 \%$ in 2013 . It is noticeable an upward oscillation occurring in 2006, when the total of turned-on TV set almost reached the same number as in 2000, achieving the mark of $45.17 \%$. This numbers oscillated down from that moment until reaching $39.74 \%$ in 2012 , the lowest number yet recorded by Ibope. In 2013, the number went up to $41.70 \%$, slightly diminishing the loss of viewers. However, despite this small recovery, the free-to-air TV in Brazil lost $8.25 \%$ of turned-on TV sets in the last 14 years. 
Rede Globo, had obtained a growth in its audience between years 2000 and 2006, when an accentuated decay started. In the first year of the analysed period, this broadcaster had $19.95 \%$ of the audience, number that rose to $21.41 \%$ in 2006 . Still, from that year on, Rede Globo has lost on average $0.8 \%$ each year, constantly diminishing its viewership. In 2013, the network reached its lowest historical rating, reaching $13.60 \%$. In other words, in seven years Rede Globo has lost 7.81 percentage points, which corresponds to more than $1 / 3$ of the audience $(36.5 \%)$.

The audience ratings of the other broadcasters had distinct behaviours. Band and RedeTV oscillated little, while SBT had a considerable loss in viewership, thus losing to TV Record the second place on the TV audience ranking that it had consolidated through the 1990's decade. In 2000, SBT had 10.41 points, a value that declined to five points in 2013. In other words, SBT lost half of its audience in 14 years.

Figure 2. Audience Oscillation During the 14 Years

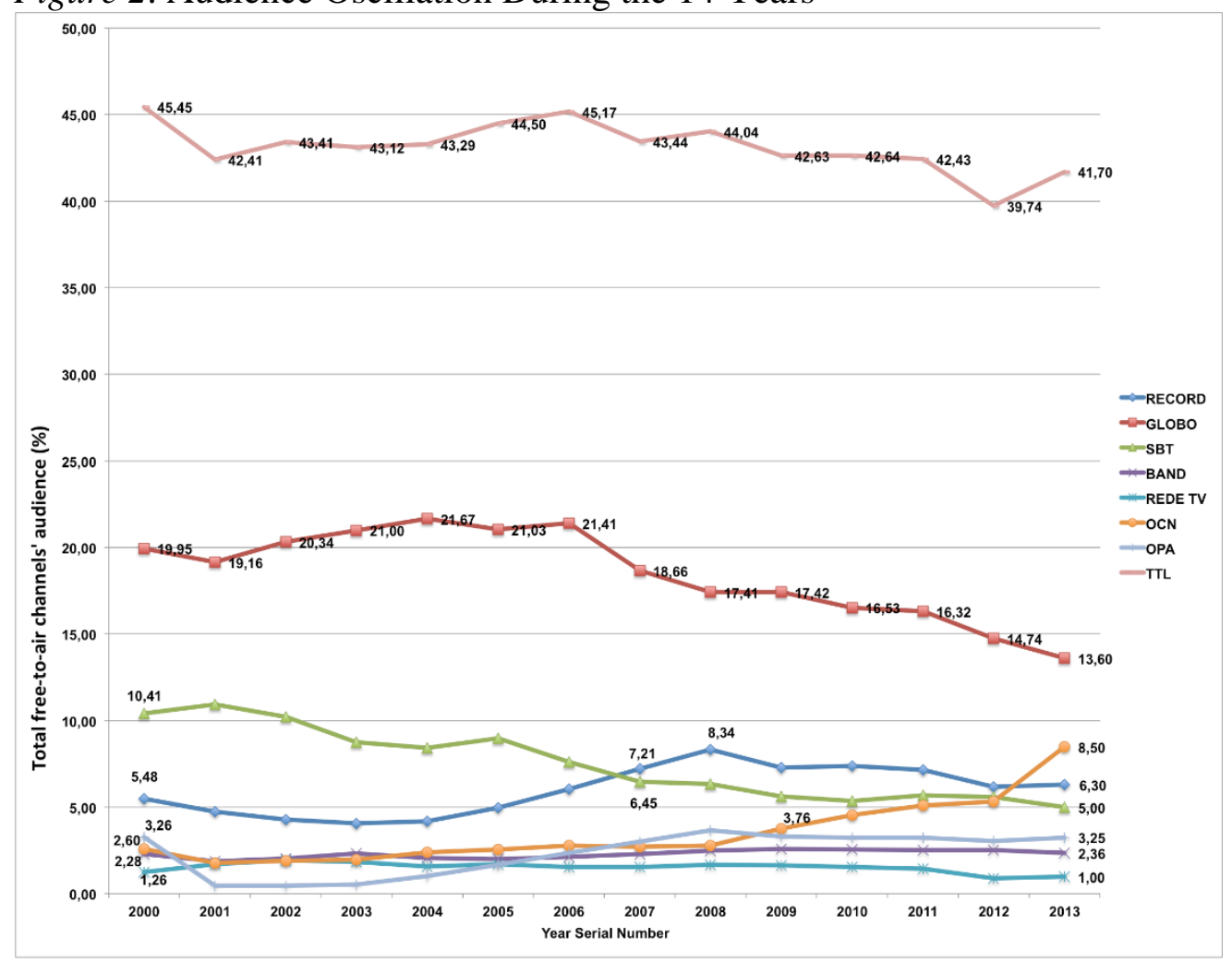

Source: Compilation of data acquired from Ibope.

Meanwhile, Record was the only TV network that registered a rise in audience during this period, surpassing SBT as a second place in 2006 - the same year this the other broadcasters' fall of the audience strengthened. From 5.48 audience points in 2000, TV Record underwent some decrease until 2004, when the curve inverted. In the same year, The Universal Church (IURD) increased the investments on the television channel (Castro, 2005; Mattos, 2007) aiming at making TV Record the leader in audience in Brazil in 10 
years. The results were positive up to 2008 and the audience ratings rose, with an average-annual rating of 8.34 points. That is, in four years the broadcaster doubled its viewership, the fruits of an ostensive commercial campaign aligned to the launch of new programming. Nonetheless, this growth did not sustain itself and Record closed 2013 with $6.3 \%$ of audience; higher than the 4.2 points in 2004, but still far from the leadership. The positive oscillation on the analysed period, especially until 2008, shows that Record partially absorbed the loss of audience of Globo and SBT. In the same period, SBT faced some difficulties derived from administrative crisis of companies from entrepreneur Silvio Santos, including the TV channel; and from constant changes in the TV programming, which directly reflected on the audience ratings.

Figure 2 also shows the behaviour of growth of other channels (OCN). In $2000,2.6 \%$ of turned-on TV Sets tuned in to other channels. This number diminished to $1.78 \%$ the following year, which can be attributed to technological changes in the measurement of OCN and pay TV. From 2002 and on, the rating for $\mathrm{OCN}$ has increased year after year by an average greater than one percent since 2008. The greatest rise was verified in the last year of the analysed period, when the number of TV sets tuned in to pay TV increased from $5.33 \%$ to $8.5 \%$, a growth of almost $60 \%$.

\section{Where Did the Audience Go?}

As shown in the previous sections, the Brazilian TV audience has been falling year after year. Nonetheless, it is necessary to investigate also the absolute numbers on viewership that the Ibope's measurement projects. In absolute numbers, in 2000 every audience point corresponded to 162,465 people. In 2013, this number rose to 185,814 viewers. Thus, in 2000 the summed audience of the five main channels corresponded to $39.37 \%$ of the population, or 6.4 million people in Sao Paulo Metropolitan Region. In 2013, this number fell to $28.26 \%$ of the population, representing 5.25 million people. In other words, the audience of aired television also decreased in absolute numbers.

What would explain this fall in the free-to-air TV audience? The present study points out that there is no single cause to this occurrence. It is a conjunction of factors that produces this trend. The expansion of pay TV and of Internet access may explain this phenomenon.

\section{The Development of Pay TV}

A central element when analysing the audience of the aired television is the pay TV, since the latter has had a nation-wide growth of more than $500 \%$ between 2000 and 2013, the analysed period. In 2000, Brazil had 3.5 million pay TV subscribers. After a relative stagnation during the beginning of last decade, this number increased year after year, in a slow pace until 2007, when it surpassed the mark of 4 million subscribers. From that point on, the growth 
has been higher than $30 \%$ per year. In 2013, the total of subscribers surpassed 18 million. Figure 3 shows the subscriptions' annual evolution, including all pay TV transmission technologies.

Figure 3. Annual Evolution of Pay TV Subscriptions

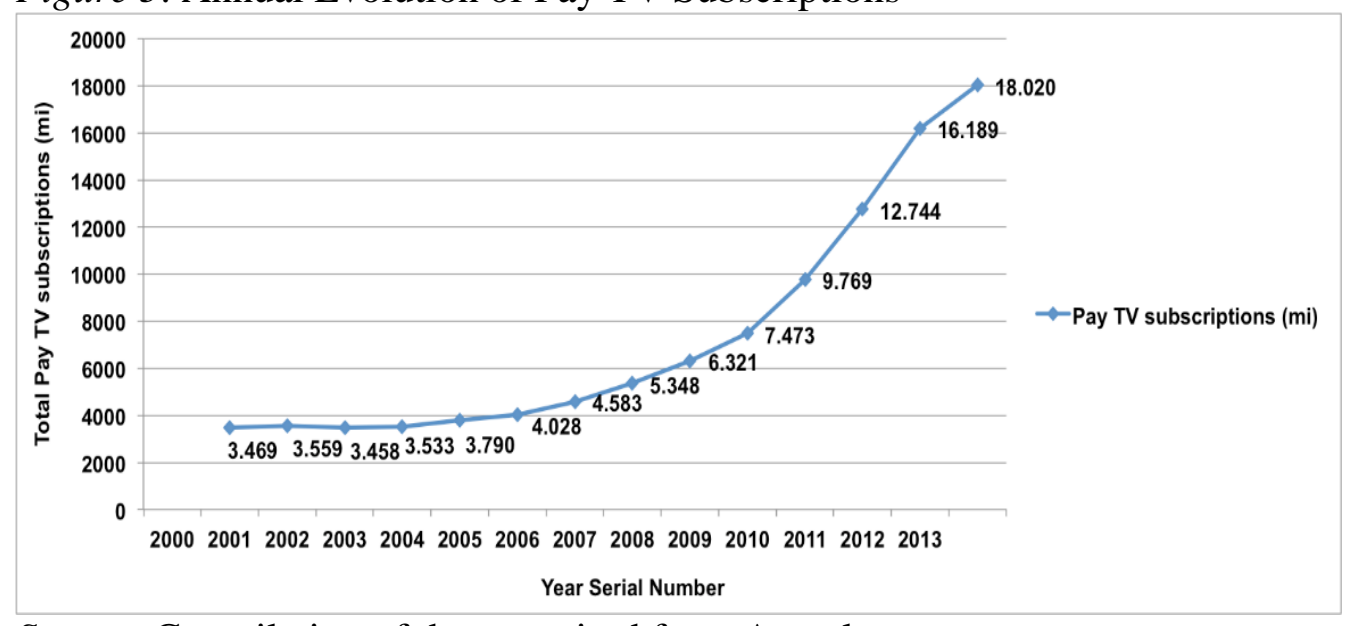

Source: Compilation of data acquired from Anatel.

Compared to the entire country, the number of subscriptions to pay TV services has grown in a slower pace in the city of Sao Paulo; it rose from 732 thousand subscriptions in 2000 to 2.5 million subscriptions in 2013, an increase of $342.5 \%$. Once OCN includes the pay TV channels in Ibope's measurement, there would be a direct relation of this number to the penetration of pay TV. It is observed that in this period, OCN's audience measured by Ibope increased by $326 \%$, reaching 8.5 points or the equivalent to 1.58 million viewers in Greater Sao Paulo. This growth can be considered statistically equivalent to the pay TV growth over the 14-years period.

\section{The Internet Impact}

The problem is even bigger concerning Internet, because there is no audience measurement that allows comparing the medium utilization flows in long timeslots. There are some metrics providing information on the quantity of accesses and the quantity of time spent on a website, but those metrics do not allow for a projection of the total viewership, something essential in the television audience. This is one of the reasons why the internet audience is referred to as number of users instead of percentage of population (Bermejo, 2007).

There are no official data of any kind on the penetration of internet in Brazil, with an expressive sample, that comprises all the years between 2000 and 2013. The CGI (Brazilian Internet Management Committee), an official organisation responsible for the administration of internet in the country, only started to consolidate such data on the internet access in 2005, available 
through its website ${ }^{1}$. In spite of this limitation, it is possible to analyse the changes in Internet penetration during the mentioned period to verify if there is any correlation with the television audience. The official survey is just adequate to show the fast growth of internet in Brazil from the middle of the past decade, both in number of accesses and in connection speed.

As shown in Figure 4, the total household access to the Internet increased by $330 \%$ between 2005 and 2013. Between 2005 and 2010, the average growth was of three percentage points, while between 2010 and 2011 one notices a leap of $11 \%$.

Figure 4. Household Internet Access and Changes in Speed of Broadband Access

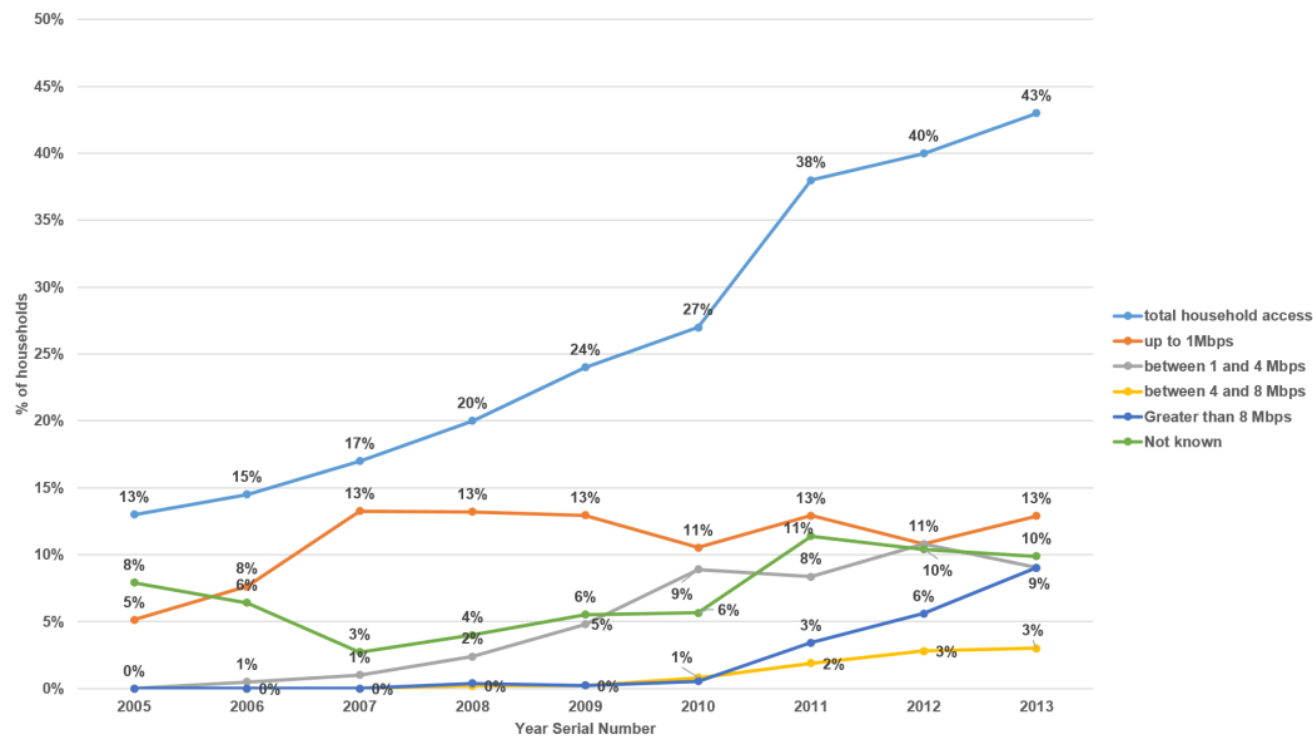

Source: Compilation of data acquired from CGI.

The speed of access also rose considerably. Until 2007, the broadband access was almost restricted to connections of up to $1 \mathrm{Mb} / \mathrm{s}$, considered insufficient for watching videos in real time and with a reasonable quality. From 2007 on, the broadband connections between 1 and $4 \mathrm{Mb} / \mathrm{s}$ started to spread. On this speed, it is possible to watch low-quality videos in real time. After 2010, the number of connections of a speed greater than $4 \mathrm{Mb} / \mathrm{s}$ started to matter, allowing the users to watch high-quality videos.

Some relationships arise from the comparison between the data on the fall of the television audience and the growth of pay TV and Internet. While the collapse of the audience ratings accelerated from 2006, both Internet and pay TV penetration rose. In 2010 and later, the fall of the audience has become even greater, while Internet and pay TV accelerated their growth in the same period.

\footnotetext{
${ }^{1}$ Available on http://www.cetic.br/pesquisa/domicilios/publicacoes.
} 
Studies have demonstrated that there is quantitative and qualitative audience migration from television to Internet (Jaffer, 2008; Liebowitz \& Zentner, 2012; Becker, 2011). Shall this hypothesis be confirmed, the loss of audience may increase over time, with continuous audience migration due to the growth of web users and the increase in data transfer speed - still a critical factor in Brazil. In other words, it is possible to affirm that the increase in pay $\mathrm{TV}$ and Internet penetration directly affects the audience of television.

\section{Changes in the TV Programming}

One effect of audience loss on aired television is the reconfiguration of the programming schedule. In the Brazilian case, it is noticeable the emphasis in some genres already historically present on TV, such as hosted live shows and factual journalism. Since 1970 decade, when the main network (TV Globo) constructed a blocked vertical and horizontal scheduling, only few adjustments have been made - most of that to incorporate more time on air and an audience that sleeps later.

As shown in Table 1, live-broadcasted and live-recorded programmes predominate in current programming, with highlights to traditional newscast and a type of news programme that emphasises sensationalism and reality television, also called infotainment. On other way, television drama programmes started bringing multiple-platform narrative structures as a bet on web and on second screen applications, to create a new relationship with their audience.

Table 1. Percentage of the Daily Schedule Occupied by Each Type of Show

\begin{tabular}{|l|c|c|c|c|c|c|}
\hline & SBT & Globo & Record & RedeTV & Band & Total \\
\hline $\begin{array}{l}\text { All News-related } \\
\text { programmes }\end{array}$ & $23.8 \%$ & $37.5 \%$ & $53.3 \%$ & $22.9 \%$ & $59.6 \%$ & $39.4 \%$ \\
\hline $\begin{array}{l}\text { All entertainment shows } \\
\text { (scripted and non- } \\
\text { scripted) }\end{array}$ & $76.3 \%$ & $62.5 \%$ & $41.7 \%$ & $49.6 \%$ & $30.8 \%$ & $52.2 \%$ \\
\hline $\begin{array}{l}\text { All live-broadcasted or } \\
\text { live-recorded shows } \\
\text { (including newscast and } \\
\text { talk-shows) }\end{array}$ & $35.0 \%$ & $55.0 \%$ & $77.5 \%$ & $48.3 \%$ & $67.1 \%$ & $56.6 \%$ \\
\hline Talk-shows & $11.3 \%$ & $17.5 \%$ & $24.2 \%$ & $42.9 \%$ & $27.5 \%$ & $24.7 \%$ \\
\hline Infotainment shows & $15.0 \%$ & $5.0 \%$ & $35.0 \%$ & $0.0 \%$ & $32.9 \%$ & $17.6 \%$ \\
\hline Telenovela & $21.3 \%$ & $25.0 \%$ & $5.0 \%$ & $0.0 \%$ & $0.0 \%$ & $10.3 \%$ \\
\hline
\end{tabular}

Source: Analysis of TV schedule published on broadcasters' websites on February 2015.

\section{Variety Shows}

Live shows, such as variety shows and newscast, present lower production costs than scripted programmes, as drama. Besides, their elastic durations offer a variety of acts, being an alternative to a broadcaster complete its scheduling. 
Thus, along with the fact that journalism has increased its space on TV programming, talk shows and variety entertainment shows have become a morning phenomenon in different broadcasters (recovering a trend that was natural in 1970 and 1980 decades). These shows can be themed (health, culinary, etc.) or not, and its main characteristic is to be an extension of the viewer's living room, receiving guests to relaxed interviews.

\section{Newscast}

The newscast language, especially the one held on live, in site coverage, feeds the viewer with a "belonging to" feeling that projects him from his actual position - as a passive spectator - to the local of action, to become part of the event, or to identify himself with the characters presented by television (Fechine, 2006). The dramatization of the news creates a contact effect in which the representation of the world becomes the own world for the viewer, a ubiquity effect that authenticates the event through a sentiment similar to voyeurism (Chareaudeau, 2010). The information credibility is one important value attributed to the newscast to attract and maintain the audience fidelity. Philo (1990) states that belief in a dominant media frame is highest among those who are most dependent on the communication media.

It is worth to point out even a change in the reference for information quality, since with the dissemination of internet and the easy access to other sources, newscast are becoming in one more medium, risking losing the leading position. To summarize, three are the characteristics of current journalism on TV.

More sensationalism. During the last few years, conservative newscasts opened more space to local news coverage, filled with everyday life events of little journalistic relevance, but of great image impact. Morning and lunchtime newscasts present longer reportages with complex narrative structure, similar to fiction. Moreover, teletabloid proliferates throughout the entire schedule, emphasising crime and violence, the curious news and celebrities' life, generally in a polemic-style coverage. Such approach to news coverage is only lesser in prime time, when the need for a more broad coverage of subjects, from quotidian facts to economics and worldwide news, makes the dramatic narrative less evident, but still present.

More intimacy. Information credibility grows with the notoriety of the agent of information, which Chareaudeau (2010) calls "right to speak". Thus, free-to-air TV creates idols through the status the journalist obtain as a legitimate fact mediator, turning him into the connexion between everyday life and spectator. Today's news programming has more discourse, manifestation and voice of the anchors. In evening newscasts, the presenters bring opinions and editorials (sometimes so polemic that they become "viral" on the internet), and the news annunciation receives loads of colloquialism. In morning and daytime newscasts, the presenters literally invite the viewer to "fell at home to an intimate chat with them". 
Increasing time of journalism during daily programming. Recently a research showed that the informative radio programming during the morning has twice the audience of television (Castro, 2014). The importance given to television outside the prime time is almost irrelevant, while the public considers Internet a more important way to media consumption during the morning and the afternoon (Grupo de Mídia Sao Paulo, 2014). TV is then forced to seek a differentiated programming. During the last decade, stations with an average audience (Record and Band) have been investing in a type of newsmagazine that mixes factual news, tabloid format and variety entertainment. The style, adapted from the American morning shows, values the image and sensationalism - examples to the infotainment shows depicted on Table 1.

\section{Other Screens}

Only recently Brazilian broadcasters have shown consistent initiatives to occupy the digital world in complement to their TV scheduling. Nonetheless, there were restrained actions until 2010, consisting mainly of webpages to some shows, blogs to special fictional series, and the distribution of excerpts of programmes online. For example, only in 2012 TV Globo reinforced investments in internet-based platforms (Cimino, 2012). In other words, for a long time digital media were treated as a menu to the broadcasted programming.

There is not an accurate measurement of the video audience on the web, but according to CGI (Brazilian Internet Committee), 56\% of Internet users usually watched video online in 2013. Besides the loss of audience, this can be a reason to broadcasters to invest in Internet content. Narrative complements and transmedia extensions is becoming part of the productions quotidian.

At the same time, the channels' webpages were transformed into assorted portals. Again, TV Globo shows the initiative of having a website do the TV broadcaster, with the programmes schedule, some news, etc. (http://redeglobo.globo.com); a video portal (http://globotv.globo.com), presenting excerpts of and full-length aired programmes, closed to subscribers; and an entertainment portal with special content, focused on web audience with web series and exclusive written news (http://gshow.globo.com).

Second screen applications have become more common and diverse: the broadcasters have a generic one, that allows to synchronically comment and share virtually any show on air; and there is the development of those dedicated to one programme, such as reality shows, aiming at a more instantaneous interaction. However, the content available to drama shows are still rare, different from what we may observe in other countries.

One main reason supporting these new interactive interfaces may be the maintenance of the younger viewership. Television has less penetration in this parcel of the population, in opposition to Internet (Brasil, 2014). Thus, TV channels continue to operate their strategy of connection and credibility toward the youngsters, but acting in a different approach from that of sensationalism in 
journalism. In this case, the notion of identification with the audience is established through web interaction and participation.

\section{Conclusions}

Studies worldwide investigate the relation between the value a person gives to information and the credibility arisen from the news. Bird (1992), Liebes (1997) and Kitzinger (1993), among others, have pointed that the news perception and given importance varies according to beliefs and personal likes. Morley (1980) concluded that social class and locality affect the value of perception of the news. Moreover, Philo (1990) and Madianou (2007) point that the existence of alternative information sources, and the grade of exposure to and dependence of a determined medium also affects the fruition of the news.

Although conducted in different countries and periods, all those studies indicate that the more options to access the news, the lesser is the possibility of one single medium to dominate attention and credibility. Digital technologies and the audience's connection through internet accentuates the changes in perceiving the information value. If some time ago television had the monopoly of information and news production and transmission, with quantitative impacts on audience ratings, today it competes with online media, of instant access, although such services still limited to one part of the population.

The loss of value as an audio-visual product reflects another important debate to journalism: the loss of credibility. Madianou (2007) shows that when people know something on the subject of the News, the perception and interpretation changes. That is, the personal experience again interferes in reception.

There is an intensifying change on what audience considers a "qualified information". Despite the increase in resolution and quality of the image brought by technological evolution, newscasts face growing difficulties in "showing the reality" and need to seek alternative forms to create and maintain proximity and familiarity bonds to the audience, thus supporting the viewership loyalty.

We showed in this study that the journalism on TV is getting closer to the infotainment genre, in different degrees according to the programme format and to the time of exhibition, but always supported by the sensationalist news and the transformation of the news presenter in a kind of entertainment host. The main objective for such strategy is to speak to an audience composed of lower-income people, whose gained importance to the publicity market from 1990 decade, along with those that usually access information through other media. The appeal of image associated to live, real-time coverage is one great differential to television, feeding the audience with a sentiment of presence and participation among others (Fechine, 2006). 
Moreover, news and live variety shows are an economically viable alternative in the morning. For many years, this period was dedicated almost exclusively to children's programming, both education-oriented or not. Since the beginning of the last decade, however, the time dedicated to this genre is shrinking when we consider the entire Brazilian TV scheduling. The last great novelty was the inclusion of one more morning newscast in TV Globo. Now there are about four consecutive hours of journalism with regional and national programmes, eliminating the children programmes from Monday-to-Friday scheduling.

This turn to informative shows appears to be the natural transition to a TV model that tries to reach an audience that seeks information in the morning, disputing with other media and, at the same time, aiming for a low-cost programming (these new programmes include analysis and interviews, which occupy a great time in the scheduling). If, on one site, the educative function television should have is lost, on the other the broadcasters develop a kind of programme that reinforces bonds, identification and credibility to the public.

Nevertheless, one question still stands: will those changes be enough to reverse the audience falling? A previous study (Becker, Gambaro, Lemos, 2015) revealed that the audience loss verified since year 2000 should accentuate during the next years, and the reason is the multiplication of means to access information through different media. Although such fading of free-toair TV viewership has not yet resulted in a significant economic impact to the broadcasters, those companies are losing their reach and influence as the main information source, to a level that seems more compatible to the present moment. Nonetheless, this could mean the loss of revenues to broadcasters in a near future. Thus, the strategies now adopted seem to be too cautious to face the business model's reconfiguration that is just happening. Those short-term strategic solutions still require some development to make possible the broadcasters do better comprehend and attend a viewership divided in multiple platforms.

\section{References}

ANATEL-Agência Nac. Telecomunicações. (2014). Anatel dados [Anatel Data]. Retrieved from http://bit.ly/1GdqGRw

Becker, V. (2011). Ambiente de medição da audiência para TV digital [Audience measurement environment for digital TV] (Doctoral dissertation). Escola Politécnica, Universidade de Sao Paulo, Brazil. Retrieved from http://bit.ly/1F9N2AL

Becker, V., Gambaro, D., Lemos, G. (2015). O impacto das mídias digitais na televisão brasileira: queda da audiência e aumento do faturamento [The impact of digital media on Brazilian TV: Fall audience and revenue growth].

Bermejo, F. (2007). The Internet Audience: Constitution \& Measurement. New York, NY: Peter Lang.

Bird, E. S. (1992). For Inquiring Minds: A Cultural Study of Supermarket Tabloids. Knoxville: University of Tennessee Press. 
Brasil-Presidência da República. Secretaria de Comunicação Social. (2014). Pesquisa brasileira de mídia 2014: Hábitos de consumo de mídia pela população brasileira [Brazilian Media research 2014: Media consumption habits by the Brazilian population]. Brazil, BR: Secom.

Castro, D. (2005, December 6). Record cresce 20\%, mas está longe do SBT. [Record grows $20 \%$, but is far from SBT.]. Retrieved from http://bit.ly/1cYMjMg

Castro, D. (2014). De manhã, rádio tem o dobro da audiência da TV aberta em SP. [In the morning, radio has twice the audience of free-to-air television in SP]. Retrieved from http://bit.ly/1F9N6AB

Cimino, J. (2012). "Globo não é apenas uma rede de TV", diz diretor-geral; emissora terá plataforma de celular. ["Globo is not just a TV network", says directorgeneral; station will have mobile platform]. Retrieved from http://bit.ly/1J4hQZr

Charaudeau, P. (2010). Discurso das Mídias [The media discourse]. Sao Paulo, BR: Contexto.

Fechine, Y. (2006). Tendências, uso e efeitos da transmissão direta no telejornal [Trends, use and effects of direct transmission on the news]. In E. B. Duarte \& M. L. D. Castro (Eds.), Televisão, entre o mercado e a academia [Television, between the market and the academy]. Porto Alegre, BR: Sulina.

Globo Domination. (2014, June 7). The Economist. Retrieved from http://econ.st/1hsxYZU

Grupo de Mídia São Paulo. (2014). Mídia Dados Brasil 2014 [Media Data Brazil 2014]. São Paulo, BR.: Grupo de Mídia

Hoineff, N. (2001). A nova televisão [The new television]. Rio de Janeiro, BR: Relume Dumará.

IBGE-Instituto Brasileiro de Geografia e Estatística. (2012). Pesquisa nacional por amostra de domicílios [National survey by sample households]. 32. Rio de Janeiro, BR: IBGE. Retrieved from http://bit.ly/1FWQB48

Jaffe, J. (2008). O Declínio da Mídia de Massa: Por que os comerciais de TV de 30 segundos estão com os dias contados? [Life After the 30-Second Spot: Energize Your Brand With a Bold Mix of Alternatives to Traditional Advertising] Sao Paulo: Mbooks.

Kitzinger, J. (1993). Understanding AIDS: Researching audience perceptions of the acquired immune deficiency syndrome. In J. Eldridge (Eds.), Getting the message: News, truth and power (pp. 271-304). London: Routledge.

Liebes, T. (1997). Reporting the Israeli-Arab conflict: How hegemony works. London: Routledge.

Liebowitz, S. J., Zentner, A. (2012). Clash of the titans: does internet use reduce television viewing?. The Review of Economics and Statistics, 94(1): 234-245.

Madianou, M. (2007). Shifting identities: banal nationalism and cultural intimacy in Greek television news and everyday life. In R. Mole (Eds.), Discursive constructions of identity in European politics (pp. 95-118). London: Palgrave.

Mattos, L. (2007, March 18). O céu é o limite. Folha de São Paulo [The sky is the limit]. Retrieved from http://bit.ly/1GCvp1X

Magalhães, M. N., Lima, A. C. P. (2011). Noções de probabilidade e estatística [Probability and statistical notions]. São Paulo, BR: Edusp.

McQuail, D. (1997). Audience Analysis. London, UK: Sage Publications.

Morley, D. (1980). The Nationwide audience: Structure and decoding. Television monograph. London: BFI.

Philo, G. (1990). Seeing and believing: The influence of television. London: Routledge. 